\title{
Spread of Endosepsis in Calimyrna Fig Orchards
}

\author{
Themis J. Michailides and David P. Morgan
}

Department of Plant Pathology, University of California, Davis, Kearney Agricultural Center, 9240 S. Riverbend Ave., Parlier 93648. Accepted for publication 9 April 1998.

\begin{abstract}
Michailides, T. J., and Morgan, D. P. 1998. Spread of endosepsis in Calimyrna fig orchards. Phytopathology 88:637-647.

Pollination of the edible fig (Ficus carica cv. Calimyrna) is mediated by a small symbiotic wasp, Blastophaga psenes, that inhabits the syconium cavity of the spring crop of fig pollinator trees (caprifigs). These fig wasps also carry propagules, mainly of Fusarium verticillioides (formerly F. moniliforme) and other Fusarium spp., which cause endosepsis, from pollinator figs to the edible Calimyrna figs in California. Spread of endosepsis was studied in one experimental and up to four commercial Calimyrna fig orchards from 1989 through 1995. The incidence of endosepsis in fruit collected from the tree canopy at either $<2.0 \mathrm{~m}$ (low) or $>2.0 \mathrm{~m}$ (high) height, from the north and south of the tree canopy, and from the outer (direct sunlight) and inner (shaded) canopy were similar.

from the source. Endosepsis decreased with distance from the source, decreasing faster to the south than in other directions from the source. In addition, the disease-vectoring wasps decreased with increased distance from the source, which also described the disease spread from the contamination source for most directions, with a sharper decline south of the source. A 3-year study in three commercial Calimyrna orchards showed there is no secondary spread of fig endosepsis in the field. Although endosepsis can complete as many cycles (three to four) as its vector in fig pollinator trees, in Calimyrna figs it is considered a monocyclic disease. Because fig wasp pollinators prefer to stay close to the contamination source when receptive Calimyrna figs are available in close proximity, only disease sources (caprifigs trees) found among Calimyrna trees or at a distance less than $50 \mathrm{~m}$ from the borders of Calimyrna orchards affect endosepsis incidence in commercial orchards.
\end{abstract} More wasps were captured in fig trees located 3.5 to $10 \mathrm{~m}$ east or west of the source than in trees 48 to $63 \mathrm{~m}$ from the source. In addition, significantly more wasps entered the syconia of trees closest ( 9 to $12.7 \mathrm{~m}$ ) to the source than the syconia of the second or third trees (18 to $38.2 \mathrm{~m}$ )
Additional keywords: caprification, disease foci, eye-end rot, Gibberella fujikuroi, gynodioecious, internal rot, mutualism, pink rot, symbiosis.
Cultivated and wild fig trees (Ficus carica L.) are unusual in that their flowers are contained within an urn-shaped inflorescence, the fig, and need a symbiotic wasp to complete pollination. The female pollinating wasp, Blastophaga psenes L., penetrates the center of the fig syconium through the ostiole when the flowers are receptive to pollination (8) and, in the process, usually loses her wings and part of her antennae $(18,36)$. Having entered a fig, the wasp is unable to leave the syconium. With the enlargement of the fig after pollination, the ostiole closes, and larvae develop inside the ovules galled by the females but only in the syconia of caprifigs. These wasp-inhabited flowers are called "gallflowers" and never develop into seeds. This process, "caprification," occurs only in pollinator trees. True pollination occurs when wasps carrying pollen from pollinator trees enter the syconia of Calimyrna trees or trees of other nonparthenocarpic fig cultivars, resulting in seed production.

Among the several fungal pathogens that infect fig fruit, Aspergillus $(6,27)$ and Fusarium spp. $(2,7,21,22,30)$ are the most common. Endosepsis (pink, brown, soft, and eye-end rots) of cultivated (mainly Calimyrna in California) and wild figs is caused primarily by Fusarium verticillioides (Sacc.) Nirenberg (formerly F. moniliforme Sheldon) and other Fusarium spp. Because the majority of Fusarium isolates from figs in California belong in Gibberella fujikuroi (Sawada) Wollenw. mating population A (30), the name $F$. verticillioides has priority over $F$. moniliforme ([17]; C. M. Liddell, personal communication). Therefore, the name $F$. verticillioides is used in this paper. Fig endosepsis has been a dilemma for fig growers for almost 75 years, because there are

Corresponding author: T. J. Michailides; E-mail address: themis@uckac.edu

Publication no. P-1998-0518-01R

(c) 1998 The American Phytopathological Society still problems with control methods (21). Endosepsis has caused considerable annual yield losses in the fig industry, so the cleanliness of male pollinator caprifig fruits is controlled by California law, and the California Fig Institute (Fresno) annually tests caprifigs as a service to its members (California Fig Institute, unpublished data).

Because endosepsis develops within the syconium cavity at a time when the ostiole is closed, only insects that can go in and out through the ostiolar scales can carry propagules of the pathogen in and out of the syconium, and wasps are well adapted for this exercise (34). Although fig endosepsis is transmitted to the Calimyrna crop by fig wasp pollinators, thrips entering before the wasps may be contaminated with Fusarium spp. and other fungal species (12). Because $F$. verticilloides sporulates abundantly inside the syconia of male pollinators, fig wasps become contaminated when they emerge and subsequently transfer the propagules either to the next crop of caprifig syconia or to the female Calimyrna crop $(2,18,29)$.

Male pollinator fig trees (hermaphrodites) produce three fruit crops of caprifig syconia: a winter crop (mamme), a spring crop (profichi), and one to two summer crops (mammoni). In California, the fig wasp completes three to four generation cycles, correponing to each developing caprifig crop $(7,21)$, and endosepsis becomes endemic in the caprifig crop, completing as many cycles as those of the emerging wasps. Because the spring crop caprifigs contain the staminate flowers (anthers), infected fruit cannot be detected or treated with fungicides to reduce endosepsis, unlike the winter crop caprifigs $(11,21,25,26,29,37)$.

All caprifig orchards are planted, in accordance with state regulations, in isolated and remote locations far from Calimyrna figs. In addition, state regulations have been imposed and methods taken to reduce excess caprifig trees, treat caprifigs by a method approved by the county commissioner, manage caprifig transportation from one location to another (allowed only in covered con- 
tainers), and destroy abandoned orchards $(21,29)$. These management practices are based on the belief that when caprifig trees are in close proximity to edible figs, growers cannot easily manage the density of flying wasps, and epidemics of endosepsis disease are unavoidable. However, there are no regulations controlling the native wild caprifig trees common along creeks in the Sierra Nevada foothills.

The presence of left-over caprifig trees in some commercial orchards and home backyards, wild caprifigs along creeks, and abandoned orchards of caprifigs in areas destined for housing on the outskirts of cities may complicate the process of pollination and, therefore, affect the spread and incidence of endosepsis despite grower attempts to treat ("clean up") the cultivated caprifigs that are to be used for pollination. If a caprifig tree is located in or near a Calimyrna orchard, the grower is asked to cut the tree down or, at least, destroy the spring crop caprifigs before wasps mature and emerge (18). Destruction of spring crop caprifigs before wasp emergence can be accomplished by spraying with ethephon (Ethrel) (5), which enhances maturation and abscission of fruit before wasps are able to escape the syconia.

Although studies on the dispersal of adult female fig wasps exist $(4,35,36)$ and the relationship between the number of wasps entering fig syconia and endosepsis incidence have been established (18), there is no published research on spatial patterns and secondary spread of endosepsis in Calimyrna orchards. The purpose of this study was to (i) describe the development of endosepsis within the cavity of Calimyrna syconium, (ii) study the spread patterns within tree canopies and among trees, and (iii) in-
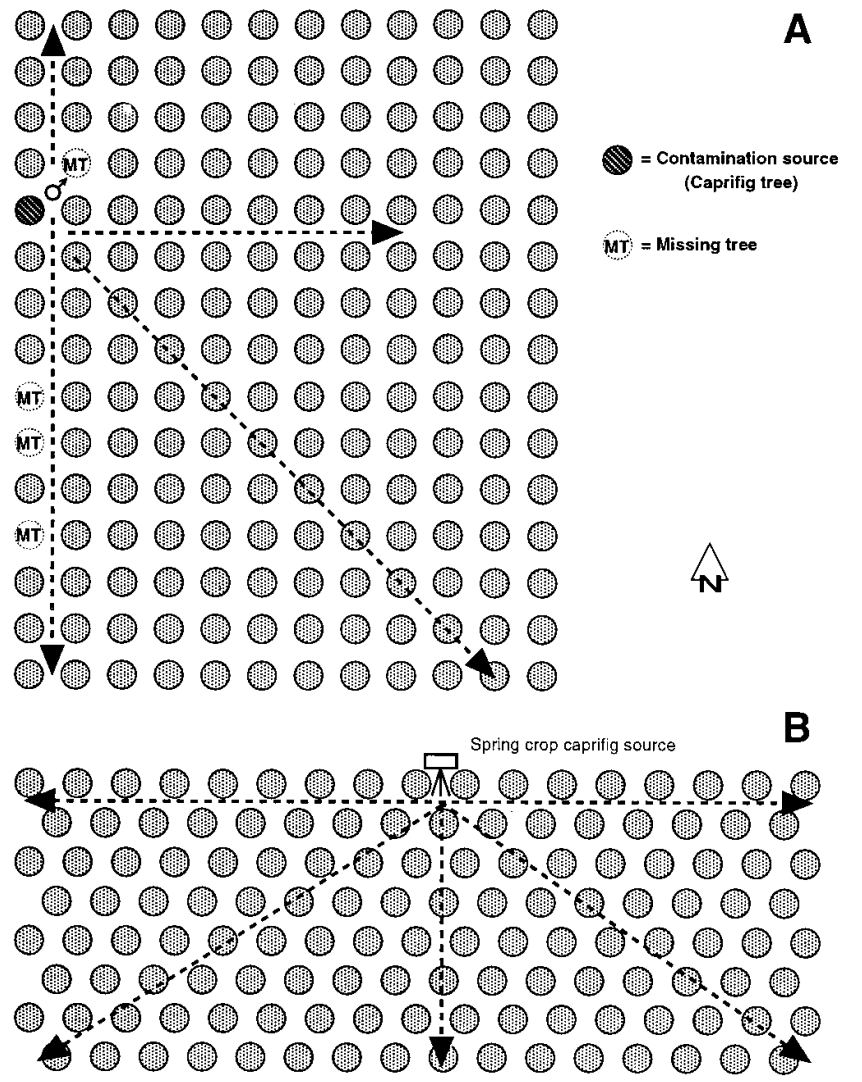

Fig. 1. Diagram A, of a commercial Calimyrna fig orchard on the northern border of Fresno, Fresno County, CA, and B, of a 0.4-ha experimental Calimyrna orchard at Kearney Agricultural Center, Parlier, CA (south of Fresno), where spread of endosepsis caused by Fusarium verticillioides was studied. A single cv. Roeding-3 caprifig tree produced a spring crop in Fresno (A) and spring crop caprifig fruit was brought into Kearney (B). Dotted lines with arrows show the directions of sampled trees (A and $\mathbf{B}$ ) and on which trees yellow adhesive traps were placed (B). (For missing trees [MT, south], the east closest tree was sampled (A). vestigate whether secondary spread of fig endosepsis occurs in Calimyrna fig orchards. The ultimate goal was to identify safe distances between plantings of Calimyrna and caprifig figs to avoid interference with effects on disease levels. A preliminary report of this research has been published (19).

\section{MATERIALS AND METHODS}

Orchards. The four (1 through 4) Calimyrna commercial orchards used in these experiments (1989 through 1995) were located in Fresno and Merced counties; the experimental orchard was located at the Kearney Agricultural Center, Parlier (Fresno County), CA.

Development of endosepsis within the syconium of Calimyrna fig. Starting 1 week after completion of pollination in 1989, 20 Calimyrna figs were collected at different stages of development (33), split, and examined with a dissecting microscope for any signs or internal symptoms of endosepsis. When conspicuous mycelia were present, they were removed with a pair of fine tweezers and plated on acidified $(2.5 \mathrm{ml}$ of a $25 \%$ [vol/vol] acetic acid per liter of medium) potato dextrose agar (APDA) to confirm the presence and identity of the pathogen (24). At later stages of fruit development, plating of mycelia was not necessary because of the characteristic color and appearance of the pathogen. Special attention was given to the development of Fusarium and other fungi on the dead wasps trapped inside the syconium cavity or among the ostiolar bracts. A total of 100 wasps was
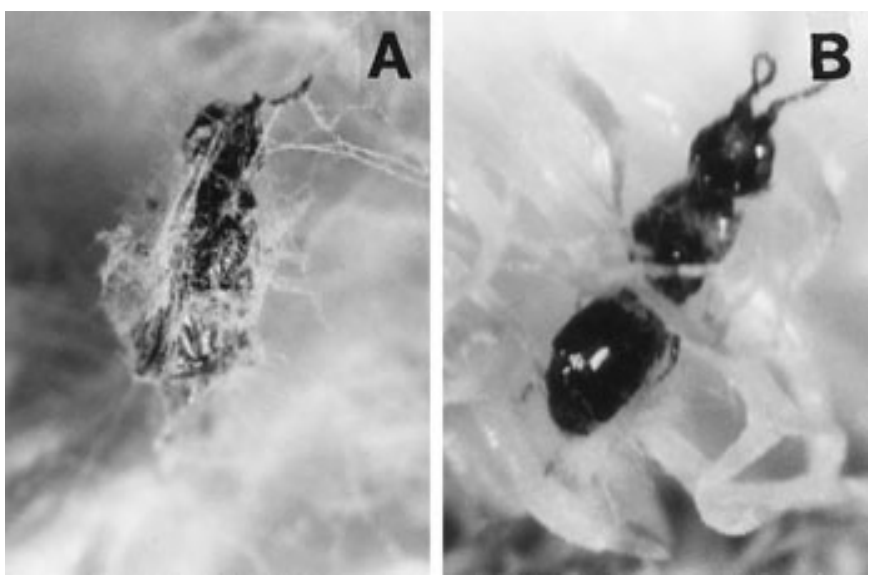

Fig. 2. A, Fusarium verticillioides growing on a dead wasp in the cavity of a Calimyrna fig syconium, and $\mathbf{B}$, a wasp not infested with $F$. verticillioides trapped in a syconium.

TABLE 1. Spread of Fusarium verticillioides (cause of endosepsis) and other fungi in syconia within the canopy of Calimyrna fig trees in a commercial

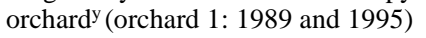

\begin{tabular}{|c|c|c|c|c|}
\hline \multirow{2}{*}{$\begin{array}{l}\text { Location of } \\
\text { canopy sampled }\end{array}$} & \multicolumn{2}{|c|}{$\begin{array}{l}\text { F. verticillioides } \\
\text { incidence }^{\mathrm{z}}(\%)\end{array}$} & \multicolumn{2}{|c|}{$\begin{array}{c}\text { Total fungi } \\
\text { incidence }^{\mathrm{z}}(\%)\end{array}$} \\
\hline & 1989 & 1995 & 1989 & 1995 \\
\hline Low $(<2 \mathrm{~m})$ & $\ldots$ & 9.2 & $\ldots$ & 36.7 \\
\hline $\operatorname{High}(>2 \mathrm{~m})$ & $\ldots$ & 16.7 & $\ldots$ & 39.2 \\
\hline $\mathrm{LSD}_{0.05}$ & & 20.3 & & 47.5 \\
\hline North & 3.9 & 8.3 & 16.7 & 28.3 \\
\hline South & 9.6 & 11.7 & 21.3 & 46.7 \\
\hline $\mathrm{LSD}_{0.05}$ & 7.6 & 19.9 & 10.4 & 62.9 \\
\hline Outer canopy (sunlight) & 2.1 & 5.8 & 3.8 & 30.0 \\
\hline Inner canopy (shade) & 2.7 & 16.7 & 3.0 & 48.3 \\
\hline $\mathrm{LSD}_{0.05}$ & 2.9 & 15.9 & 3.9 & 59.1 \\
\hline
\end{tabular}

y This and two other similar orchards, where these experiments were repeated, were located in Merced County, CA.

${ }^{\mathrm{z}}$ Incidence of various fungi in the syconia was determined by the agar-drop technique (20). Average of 3 samples of 20 figs each, collected from 3 arbitrary trees per orchard on 9 September 1989 and 27 July 1995. 
removed with a pair of fine tweezers and plated on APDA plates (10 wasps per plate).

Distribution of endosepsis within tree canopies. In three commercial orchards, from three replicate trees each, two samples of 20 Calimyrna figs were collected arbitrarily: one each from the upper $(>2 \mathrm{~m})$ canopy and one each from the lower $(<2 \mathrm{~m})$ canopy of each tree on 9 September 1989. In a second experiment, two similar samples of 20 figs each were collected arbitrarily from three replicate trees: one each from the south and north of each tree canopy (composite samples from the outer and inner canopies) at 1.5 to $2.5 \mathrm{~m}$ height. In a third experiment, two similar samples of 20 figs each were collected arbitrarily: one each from the outer (direct sunlight) and inner (shaded) canopies from three arbitrarily chosen trees in these orchards. Either on the day of collection or after storing the figs at 1 to $2^{\circ} \mathrm{C}$ overnight, all figs were surface-disinfected with $0.08 \%$ sodium hypochlorite solution for $3 \mathrm{~min}$, allowed to dry, split in half, and processed, using the agar-drop technique (20) to determine the levels of $F$. verticillioides and other fungal species growing on the solidified agar drops after 4 days of incubation at $23^{\circ} \mathrm{C}$. All experiments were repeated on 27 July 1995.

Spread of endosepsis in a commercial orchard. Spread of endosepsis from a pollinator caprifig, cv. Roeding-3, tree (contamination source) to the fourth (north), seventh (south and east), and eighth (southeast) Calimyrna trees from the source was studied in 1992 and 1993 in a commercial orchard in Fresno County (Fig. 1A). The spring crop caprifigs (profichi) were left to mature on the tree and release adult female fig wasps in this orchard. On 1 July 1992, $\approx 1$ month after the completion of pollination, 40 green fruits were collected arbitrarily from a height of 1.5 to $2.5 \mathrm{~m}$ around the canopy of each of four (north), seven (south and east), and eight (southeast) Calimyrna trees from the caprifig tree. All figs were surface-disinfected with $0.08 \%$ sodium hypochlorite and processed, using the agar-drop technique to determine the incidence of $F$. verticillioides as previously described (20). The experiment was repeated on 15 July 1992 and 1 July 1993 in the same orchard.

In addition, 10 pollinated figs were collected arbitrarily from each of three trees (1T, 2T, and 3T) 9, 18, and $27 \mathrm{~m}$ to the north, east, and south, and 12.7, 25.4, and $38.2 \mathrm{~m}$ to the southeast, respectively, from the pollinator tree, split into halves, and the number of wasps trapped in the syconia was observed with a dissecting microscope (magnification 10 to $20 x$ ) and recorded.

Because figs mature on the trees, dry slowly, drop to the ground, and periodically are swept up, commercial figs have multiple harvests. During commercial harvest, 50 dried figs were collected from the ground under each of four (north), seven (south and east), and nine (southeast) Calimyrna trees from the caprifig tree. The figs were
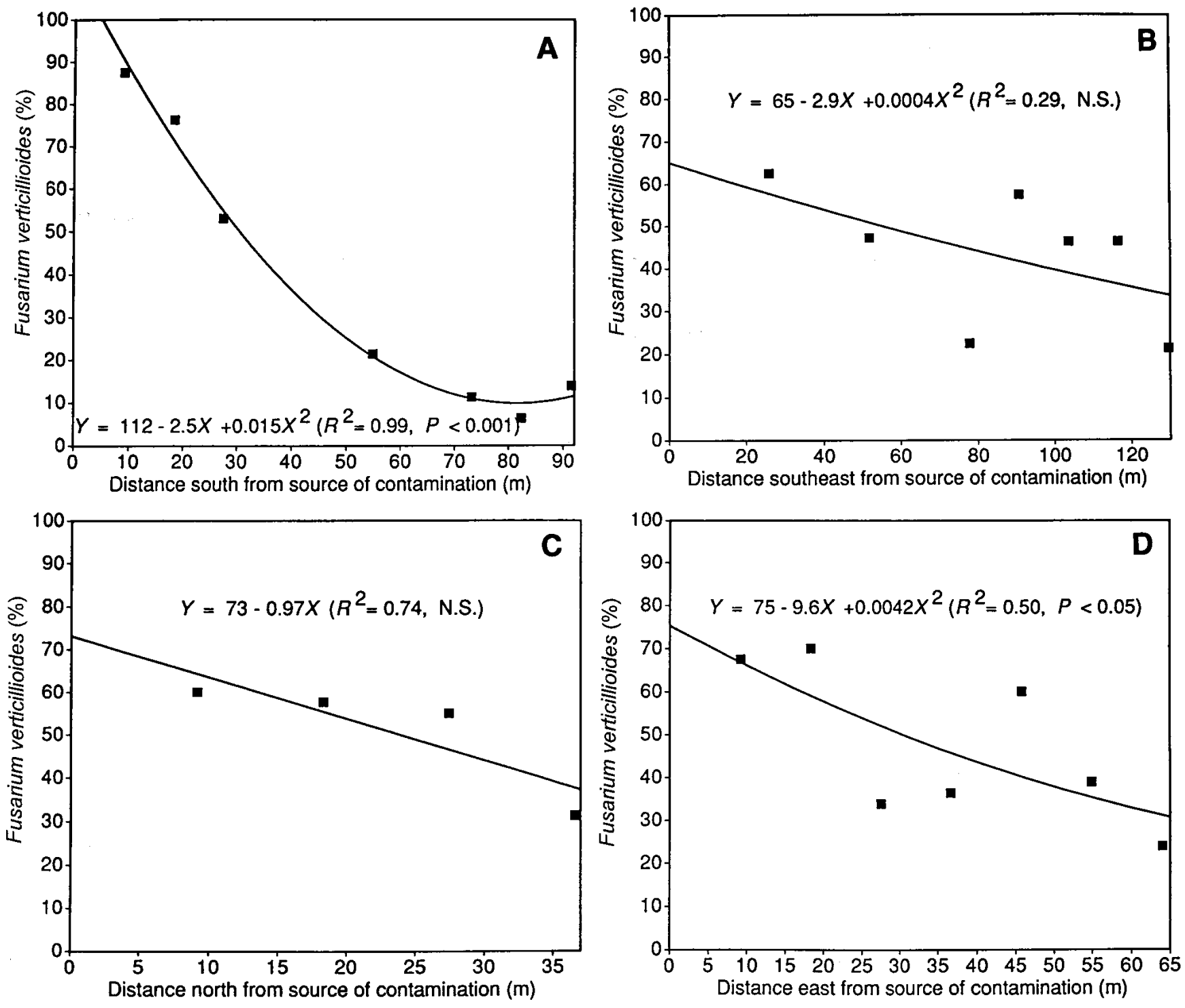

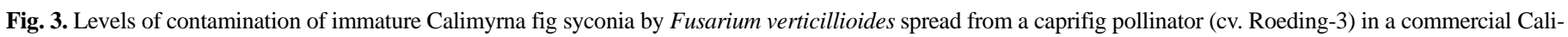
myrna orchard (Fig. 1A) in 1992 in four directions from the source: A, south; B, southeast; C, north; and D, east. Values are based on averages from 40 figs per tree. 
split in half and examined with a dissecting microscope (magnification 10 to $20 \times$ ) for the presence of endosepsis in the fruit cavity indicated by the presence of white to light pink mycelium, with a powdery appearance due to profuse sporulation of Fusarium spp. $(21,22)$.

Spread of endosepsis in an experimental Calimyrna orchard. The spatial spread of the disease from the contamination source also was studied in an experimental 0.4-ha Calimyrna orchard, planted in a $7 \times 7-\mathrm{m}$ diamond design (Fig. 1B) at the Kearney Agricultural Center, Parlier. When fig fruit was receptive for pollination, three identical wooden boxes $(30 \times 50 \times 25 \mathrm{~cm})$, containing, respectively, 481,426 , and 400 spring crop caprifigs (profichi), were placed among the canopies of two trees $(1.5 \mathrm{~m}$ high) on a wooden quadropodic stand (Fig. 1B) in the northern border row of trees. The boxes containing spring crop caprifigs were brought into the orchard on 8,15 , and 23 June 1993 and 12, 19, and 26 June 1995. Each box containing caprifigs was left in the orchard until it was replaced by another identical box containing a second batch of fresh spring crop caprifigs. Caprifigs used on 8 and 15 June 1993 and 12 and 19 June 1995 were collected fresh daily from a commercial caprifig orchard in Tulare County; those used on 23 June 1993 and 26 June 1995 were collected on 15 and 19 June, respectively, and refrigerated at $10^{\circ} \mathrm{C}$ until used. Because fig wasps are very sensitive to temperatures elevated only a few degrees above ambient (13), to shade the spring crop caprifigs and protect emerging wasps from direct sunlight, a second empty wooden box $(30 \times 50 \times 25 \mathrm{~cm})$ was placed on top of the box containing caprifigs, leaving a rectangular opening of $3 \times 45 \mathrm{~cm}$ on both the north and south sides of the lower box to allow the wasps to exit. The incidence of $F$. verticillioides developing in fruits was recorded in 20 Calimyrna figs collected arbitrarily on 10 August 1993 and repeated with 40 figs from each sampled tree on 24 July 1995. Sampling trees included eight east, nine west, and six each south (in a zigzag pattern), southwest, and southeast (Fig. 1B). Figs were brought to the laboratory and processed by the agar-drop technique (20) the day of or day following collection.

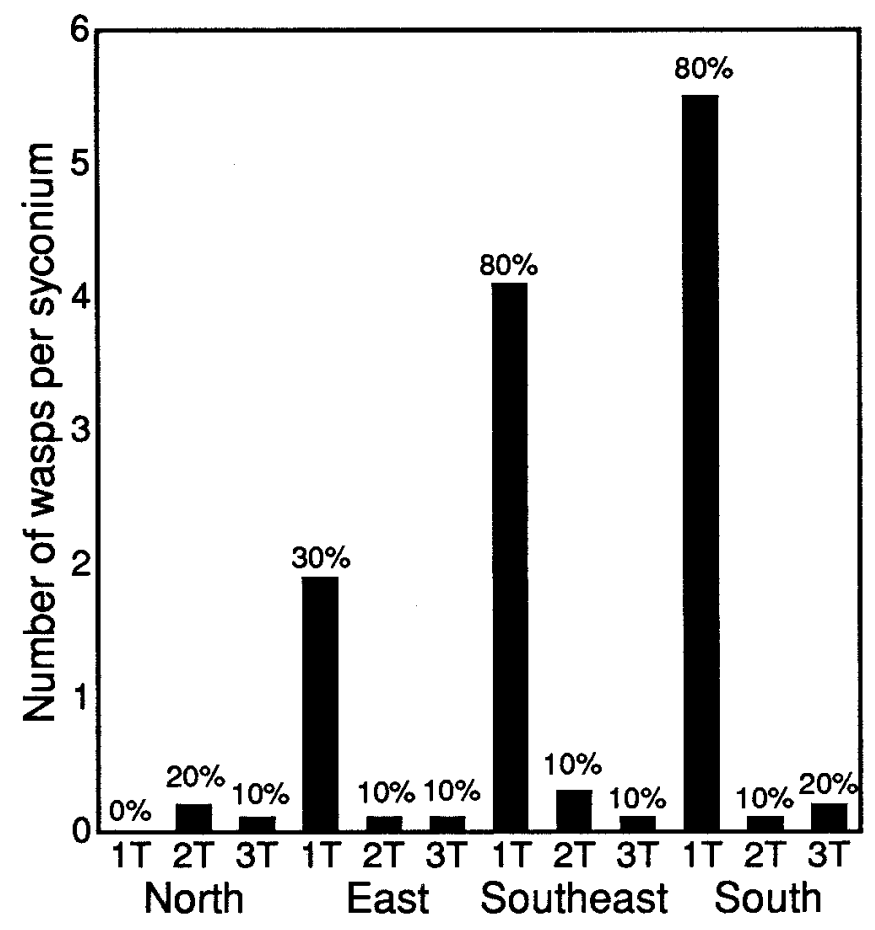

Fig. 4. Numbers of wasps in Calimyrna fig syconia collected from the three trees $(1 \mathrm{~T}, 2 \mathrm{~T}$, and 3T) closest to the pollinator caprifig tree in four directions. Bars represent the average from 10 figs collected on 1 July 1992. Percents indicate figs with at least one wasp in the syconium; the experiment was repeated on 1 July 1993.
Wasp monitoring. To monitor the populations of flying wasps, yellow adhesive traps $\left(406.5 \mathrm{~cm}^{2}\right.$ area with adhesive) without pheromone (Pherocon A.M. Trap, Trécé, Inc., Salinas, CA) were hung open one per tree, using a total of eight (east) to nine (west), six to seven (south), six (southeast), and six (southwest, only in 1995) traps on 8 June 1993, including all the trees sampled for diseased fruit. The effectiveness of these traps in catching fig pollinator wasps was tested previously (18). The traps were collected 1 week to 10 days later, the number of wasps per trap was observed with a dissecting microscope (magnification 10x) and recorded, and the traps were replaced with a second set of clean traps. A third set of traps was hung on the same trees after collection of the second set of traps and collected 1 week later. A similar number of traps was placed on the same sampled trees for all tested directions, including southwest, in 1995. Environmental conditions, such as maximum and minimum daily temperatures, relative humidity, and wind directions, were obtained from the weather station located $\approx 200 \mathrm{~m}$ south of the experimental fig orchard.

Secondary spread of fig endosepsis. Secondary spread of fig endosepsis in the field (from the time pollination is completed until the fruit is harvested) was studied simultaneously in three commercial orchards in Merced County in 1989, 1990, and 1991. After the completion of pollination, 14,49 , and 30 shoots in 7 trees in orchard $1 ; 14,51$, and 31 shoots in 8 trees in orchard 2; and 14, 28, and 32 shoots in 8 trees in orchard 3, respectively, on 15 July 1989, 14 July 1990, and 10 July 1991 were flagged; approximately half of the shoots in each orchard were covered with an organdy bag $(100 \times$ $50 \mathrm{~cm} ; 180$ threads per $\mathrm{cm}^{2}$ ). Each of these shoots had at least 10 but not more than 24 figs. The bags excluded nitidulid beetles (Carpophilus spp.), drosophilid flies (Drosophila spp.), and other relatively large insects (i.e., rhopalid hemipterum, Liorhyssus hyalinus, or navel orangeworm, Amyelois transitella, but not thrips and mites). The rest of the flagged shoots were covered with mesh ( $0.5 \mathrm{~cm}$ opening) bags to allow free movement of nitidulid beetles, drosophilid flies, and other larger insects and, at the same time, collect in them any figs that might have dropped before harvest. The bags were left on the shoots until commercial harvest on 31 August 1989, 6 September 1990, and 26 September 1991, when all fruits were harvested and brought to the laboratory for evaluation of fig endosepsis. All the fruits were split in half, and endosepsis was determined with the aid of a dissecting microscope (magnification 10 to $20 \times$ ) as previously described.

Statistical analyses. The design of each experiment to determine the incidences of endosepsis of fruit from the low and high, north and south, and outer and inner canopies was randomized, with three replications of 20 fruits per tree. Data were analyzed by analysis of variance (ANOVA) to determine the effect of canopy direction on the distribution of endosepsis, and differences among means were compared with Fisher's protected least significance difference (LSD) test at $P=0.05$. All the data on the spread of disease from the source were analyzed by regression analyses, using the distance (meter) from the source of "contaminated" wasps as the independent variable (SAS Statistics, release 6.04, SAS Institute Inc., Cary, NC). The relationships between the distance from the contamination source and the incidence of $F$. verticillioides or endosepsis also were determined with regression, using SAS. The experimental design to determine secondary spread of fig endosepsis was completely randomized, with 7 to 26 replications, repeated in three orchards in 3 years. Data for the secondary spread of disease were analyzed by ANOVA to determine the effects of covering fig shoots on the incidence of endosepsis, and treatment mean differences were compared with Fisher's protected LSD test at $P=0.05$. Because results were similar among orchards and years, they also were compared after combining all orchards for each year and all years for each orchard. The relationships between the distance from the source of emergence and the wasps trapped were determined by SAS regression analyses. The relationship between wasp population and incidence of $F$. verticillioides was determined by regression. (Data were 
combined for 1993 and 1995 because the trends in wasp trapping and incidence of the pathogen were similar.)

\section{RESULTS}

Development of endosepsis within the fig syconium. Within 2 to 3 weeks of completion of pollination, the styles of inflorescences developed a golden yellow to rusty brown discoloration around dead wasps. Usually, these yellow or brown symptoms extended to the ostiolar channel or the base of the ostiolar bracts. After 2 to 3 weeks and before the appearance of any symptoms of endosepsis in the fruit cavity, mycelia of $F$. verticillioides were evident on infested dead wasps trapped in the syconium. Later in the season (beginning of July), sporulation of $F$. verticillioides on wasps bodies that did not extend into the fruit tissues was common. As the fruit began to mature (beginning of August), however, mycelial strands with abundant sporulation (phialides and microconidia, resulting in a powdery appearing colony) extended from wasp bodies into the surrounding fruit tissues (Fig. 2A). Occasionally, other fungi, such as Paecilomyces lilacinus and Cladosporium or Penicillium spp., whether accompanied by $F$. verti-
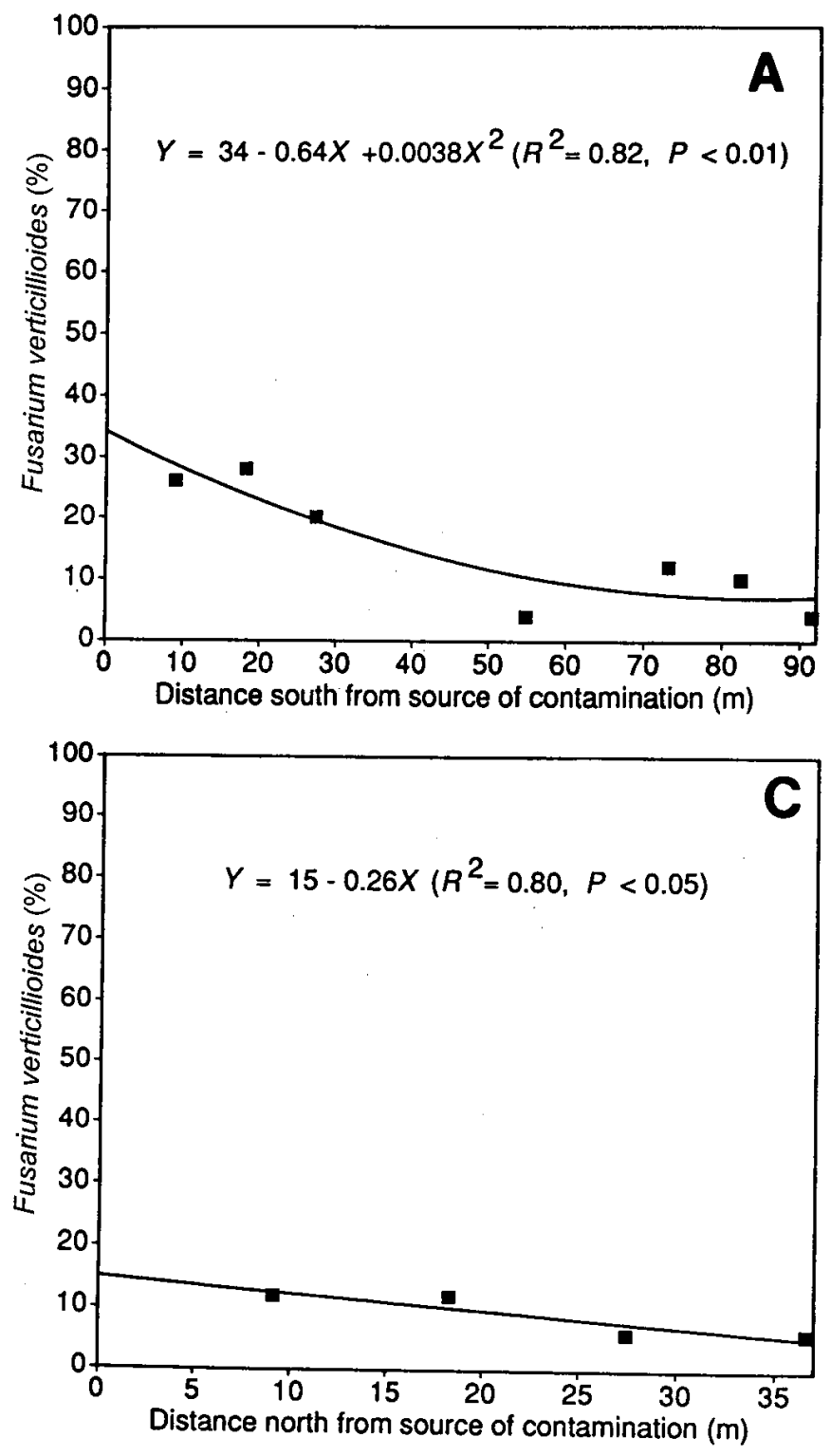

cillioides, covered the wasps. The bodies of noninfested wasps trapped in the syconium cavity remained free of any mycelial growth and appeared shiny black (Fig. 2B). Figs with $F$. verticillioides in the cavity also commonly had $F$. verticillioides in the ostioles, and there were instances when the fungus was present in the ostiole but not in the cavity.

Distribution of endosepsis within tree canopies. In all orchards sampled during both years, the incidence of $F$. verticillioides in fruit harvested from the low or high canopies of trees did not differ significantly (only data for orchard 1 are shown; Table 1). In general, higher levels of $F$. verticillioides and total fungi were recorded in 1995 than in 1989. Neither the incidences of $F$. verticillioides nor of other fungal species differed for fruit collected north rather than south of the source trees in the three orchards for both years of sampling. Similarly, neither the incidences of $F$. verticillioides nor of other fungal species recorded in fruit collected from the outer tree canopy (direct sunlight) differed from that in fruit collected from the inner tree canopy (shaded areas) (Table 1). The most common recorded fungi other than $F$. verticillioides were species of Alternaria, Ulocladium, and Aspergillus (the latter mainly of section
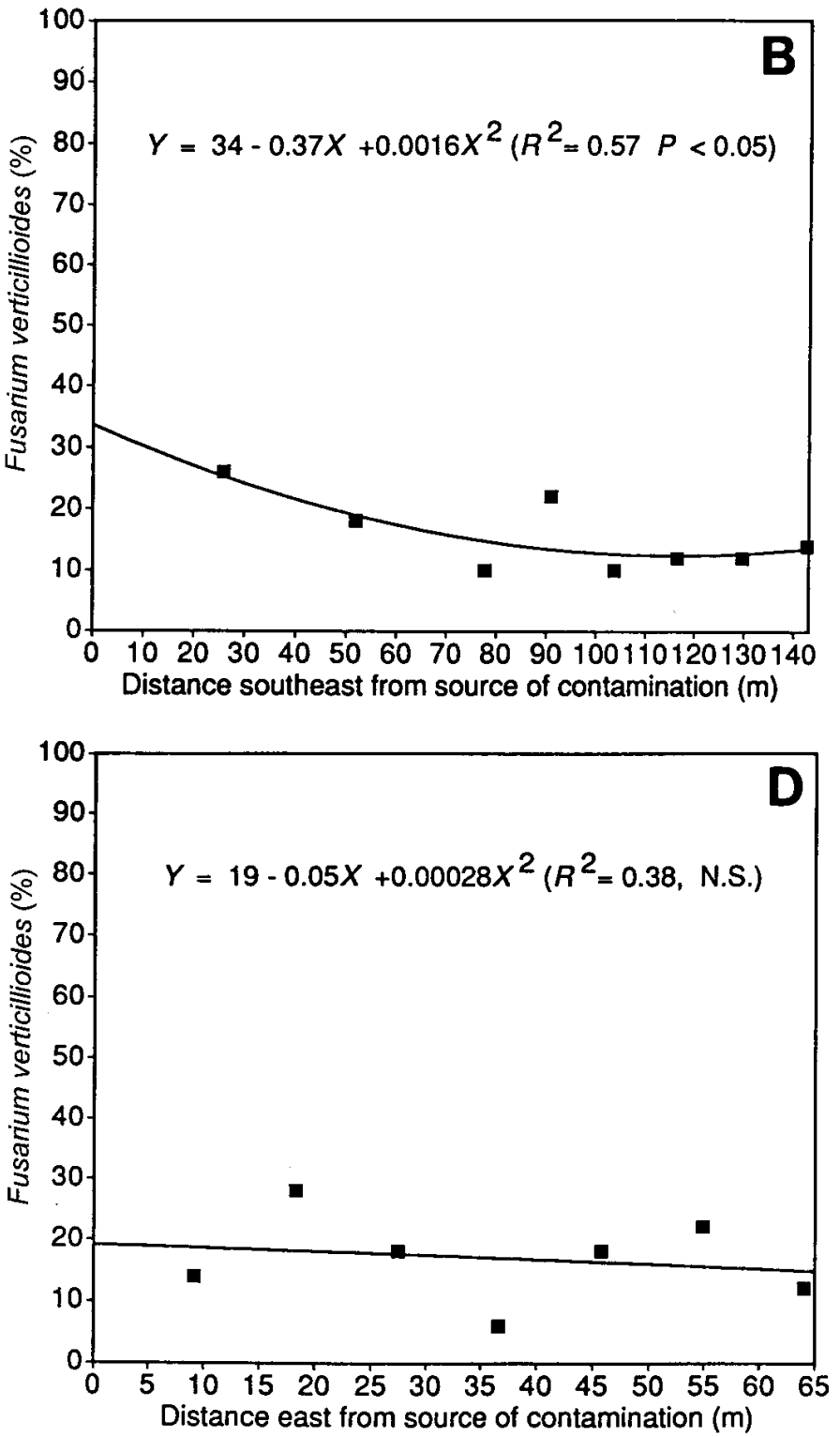

Fig. 5. Levels of contamination of immature Calimyrna fig syconia by Fusarium verticillioides spread from a caprifig pollinator (cv. Roeding-3) in a commercial Calimyrna orchard (Fig. 1A) in 1993 in four directions from the source: A, south; B, southeast; C, north; and D, east. Values are based on averages from 40 figs per tree. 
Nigri). Results were similar in orchards 2 and 3 in either year of the study (data not shown).

Disease spread in a commercial Calimyrna orchard. In the immature fruit used in the commercial Calimyrna orchard (Fig. 1A) in 1992, the incidence of $F$. verticillioides decreased with distance south and east from the contamination source (caprifig tree) (Fig. 3A and D). Fruit from trees next to the caprifig pollinator to the south, southeast, north, and east had 88, 64, 60, and $68 \% F$. verticillioides incidence, respectively, whereas the levels of contamination of immature fruit decreased to $15,20,31$, and $22 \%$ for the seventh, seventh, fourth, and seventh trees to the south, southeast, north, and east, respectively, from the caprifig tree. The incidence of $F$. verticilloides declined steeply to the south with increased distance from the source (Fig. 3A), whereas the reduction to the east was smaller (Fig. 3D). The incidence of $F$. verticillioides in figs collected from trees to the southeast and north did not follow any particular pattern (Fig. 3B and C).

The majority $(80 \%)$ of the fig syconia collected from the closest tree southeast and south of the contamination source contained an average of 4.1 to 5.5 wasps per fig syconium (Fig. 4), whereas only $30 \%$ of the figs from the first tree to the east had an average of 1.9 wasps per syconium. A smaller number $(\leq 0.3)$ of wasps per syconium was recorded in only 10 to $20 \%$ of the fig syconia that were collected from the second or third tree to the north of the contamination source (Fig. 4). A second sampling of green fruit provided similar results.

In general, the levels of infection of figs by $F$. verticillioides were lower in 1993 than in 1992 (Figs. 3 and 5), but again in 1993, the incidence of $F$. verticillioides decreased with increased distance to the south, southeast, and north (Fig. 5A through C) but did not decrease with increased distance to the east from the contamination source (Fig. 5D).

In 1992 the incidence of $F$. verticillioides in dry Calimyrna fruit sampled from trees to the south or southeast (Fig. 6A and B) followed patterns similar to those recorded for immature fruit (Figs. $3 \mathrm{~A}$ and $5 \mathrm{~A}$ and $\mathrm{B}$ ). The disease levels decreased with increased distance to the south and southeast (Fig. 6A and B) but did not decrease with increased distance to the north and east of the caprifig pollinator tree (Fig. 6C and D). However, these incidences were smaller than those recorded in immature fruit (Figs. 3 and 5).

Disease spread in an experimental Calimyrna orchard. Because disease spread results were similar between the two years, only results from 1995 are shown. During both years, the incidence of $F$. verticillioides decreased with increased distance south, southeast, southwest, and east from the source. In 1993 incidence decreased more $(P<0.05)$ toward the south than the southeast,
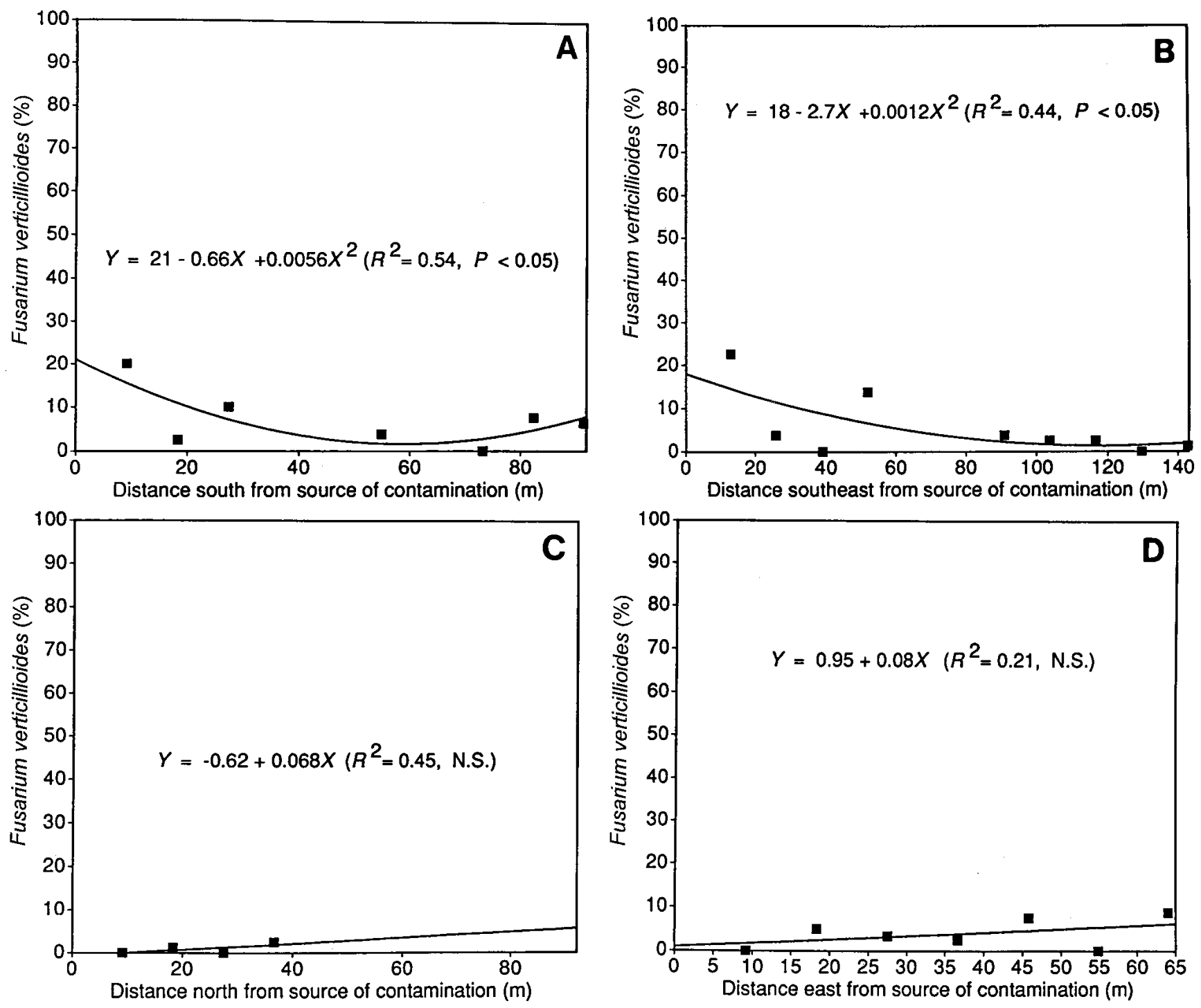

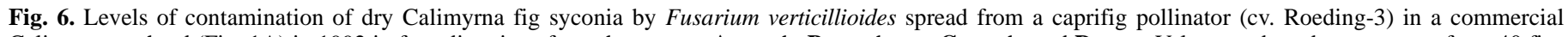

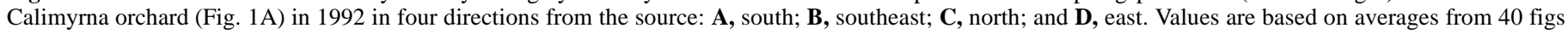
per tree. 
west, southwest, or east (data not shown) and in 1995 decreased more $(P<0.05)$ toward the south or west (Fig. 7A and $\mathrm{C}$, respectively) than the southeast, southwest, or east (Fig. 7B, D, and $\mathrm{E}$, respectively). The incidence of $F$. verticillioides decreased with distance as far as 30 to $35 \mathrm{~m}$ from the contamination source (Fig. 7). During both years, this decrease in pathogen incidence with increasing distance from the source was best described by seconddegree polynomial equations $(P<0.01$ to 0.001$)$ (Fig. 7). In 1995,
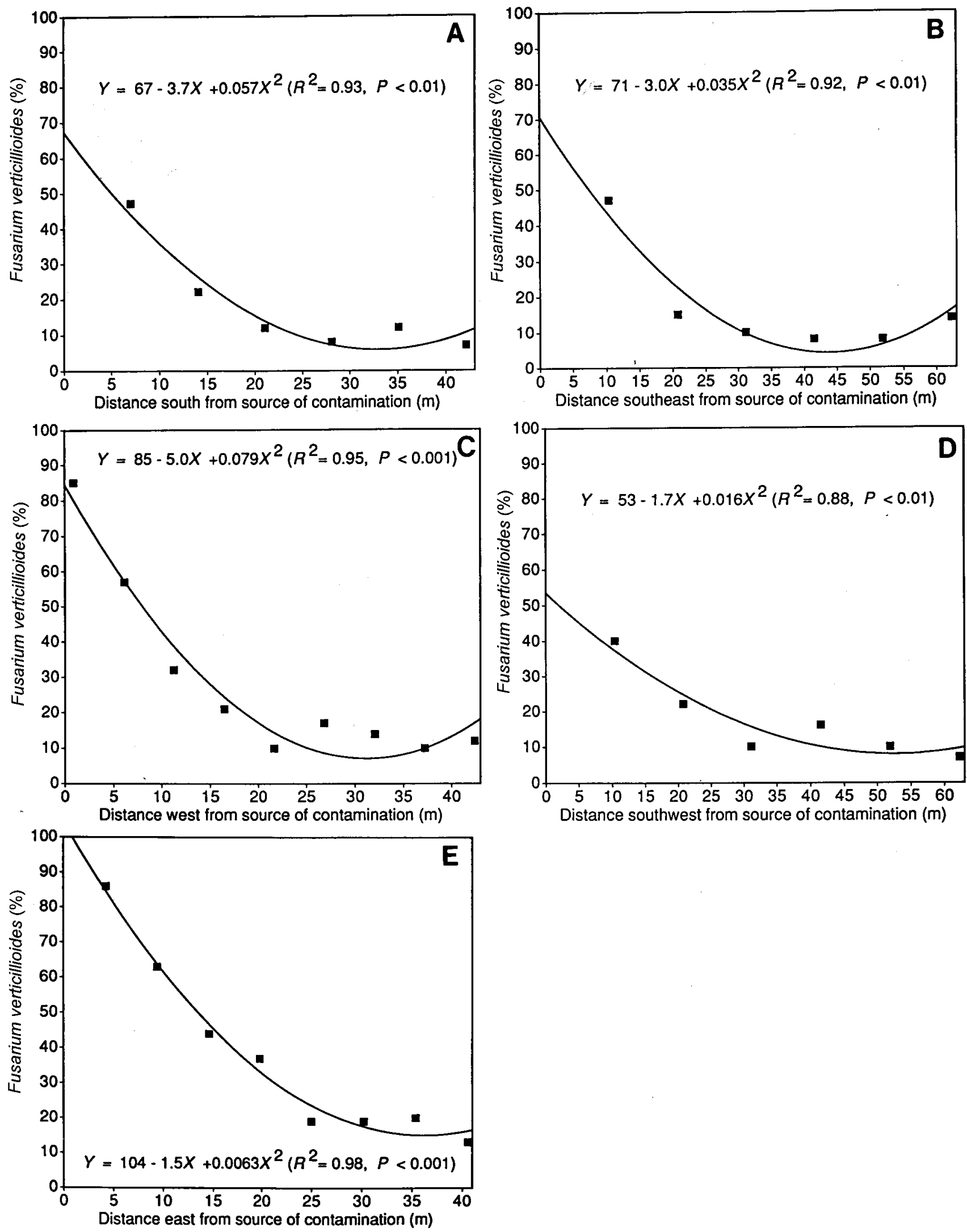

Fig. 7. Levels of contamination of immature Calimyrna fig syconia by Fusarium verticillioides spread by wasps emerging from a box containing spring crop caprifigs (source of contamination) in an experimental Calimyrna orchard (Fig. 1B) in Parlier, CA, in 1995 in five directions from the source: A, south; B, southeast; $\mathbf{C}$, west; $\mathbf{D}$, southwest; and $\mathbf{E}$, east. Values are based on averages from 40 figs per tree. 
more than $80 \%$ of the fruits from the first two trees west and east of the source contained $F$. verticillioides (Fig. 7C and E). The incidence of $F$. verticillioides in fruits from the closest tree to southwest of the source (Fig. 7D) was lower than in fruits from the trees closest to the source in the other directions. Dried figs were not evaluated for endosepsis in this orchard because of severe insect (nitidulid beetles and drosophilid flies) infestation and sour rot at harvest, making endosepsis evaluation impossible.

Wasp monitoring. In both years of wasp trapping, most of the wasps were trapped on trees west or east (Table 2) of the source. The number of wasps declined sharply with distance, more so to the west and east than in the other directions in which traps were hung. Traps placed on trees on 1 July and removed on 9 July 1993 trapped no wasps to the east and south, but five wasps were captured on traps placed west of the source. During wasp-trapping periods, greater average maximum temperatures $\left(31.3\right.$ to $\left.34.7^{\circ} \mathrm{C}\right)$ were recorded in 1993 than in $1995\left(26.2\right.$ to $\left.33.8^{\circ} \mathrm{C}\right)$, whereas the average minimum temperatures were about the same (Table 3 ). In contrast, higher average maximum relative humidity and smaller average minimum relative humidity were recorded in 1995 than in 1993. The prevailing winds in this orchard were northwesterly and westerly in 1993 and northwesterly in 1995 (Table 3). In both years of wasp trapping, more than $80 \%$ of the wasps flying were trapped in traps hung on the western tree closest $(3.5 \mathrm{~m})$ to the source (Table 2). Similarly, of the wasps flying east, more than $75 \%$ (1993) and more than 45\% (1995) were trapped in traps hung on the eastern tree closest $(3.5 \mathrm{~m})$ to the source (Table 2). In general, for all directions, the levels of wasps trapped decreased with distance from the source. The decline in numbers of wasps in traps hung $63 \mathrm{~m}$ away from the source was the smallest (8 to $11.5 \%$ of the wasps were trapped) for the southeast and southwest (Table 2).

Relationship of wasp populations and incidence of endosepsis. The incidence of $F$. verticillioides detected in fig fruit increased exponentially $(P<0.001)$ with the number of wasps caught in traps (Fig. 8). During both years, the incidence of $F$. verticillioides

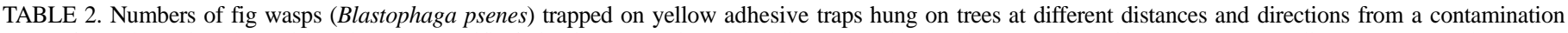
source for endosepsis (a box with spring crop caprifig fruits) in an experimental Calimyrna orchard at the Kearney Agricultural Center, Parlier, CA (1993 and 1995)

\begin{tabular}{|c|c|c|c|c|c|c|c|}
\hline \multirow[b]{2}{*}{ Year $^{\mathrm{x}}$} & \multicolumn{2}{|c|}{ Distance $(\mathrm{m})$} & \multicolumn{5}{|c|}{ Total no. and \% of wasps trapped per trap ${ }^{y}$} \\
\hline & $\begin{array}{c}\text { West and } \\
\text { east }\end{array}$ & $\begin{array}{c}\text { Southeast and } \\
\text { southwest }\end{array}$ & $\begin{array}{c}\text { South } \\
\text { no. }(\%)\end{array}$ & $\begin{array}{c}\text { Southeast } \\
\text { no. }(\%)\end{array}$ & $\begin{array}{c}\text { West } \\
\text { no. }(\%)\end{array}$ & $\begin{array}{c}\text { Southwest } \\
\text { no. }(\%)\end{array}$ & $\begin{array}{c}\text { East } \\
\text { no. }(\%)\end{array}$ \\
\hline 1993 & $\begin{array}{r}3.5 \\
10.5 \\
17.5 \\
24.5 \\
31.5 \\
38.5 \\
45.5 \\
52.5 \\
59.5\end{array}$ & $\begin{array}{l}10.5 \\
21.0 \\
31.5 \\
42.0 \\
52.5 \\
63.0\end{array}$ & $\begin{aligned} & 93(49.2) \\
& 42(22.2) \\
& 18(9.5) \\
& 11(5.8) \\
& 7(3.7) \\
& 13(6.9) \\
& 5(2.7) \\
& \ldots \\
& \ldots\end{aligned}$ & $\begin{array}{c}282(56.5) \\
136(27.3) \\
17(3.4) \\
8(1.6) \\
16(3.2) \\
40(8.0) \\
\ldots \\
\ldots \\
\ldots\end{array}$ & $\begin{array}{c}3,912(80.3) \\
299(6.1) \\
239(4.9) \\
130(2.7) \\
92(1.9) \\
63(1.3) \\
34(0.7) \\
48(1.0) \\
50(1.1)\end{array}$ & $\begin{array}{l}\cdots \\
\cdots \\
\cdots \\
\cdots \\
\cdots \\
\cdots \\
\cdots \\
\cdots \\
\cdots\end{array}$ & $\begin{array}{c}3,135(77.8) \\
331(8.2) \\
152(3.8) \\
107(2.7) \\
143(3.5) \\
68(1.7) \\
32(0.8) \\
63(1.5) \\
\ldots\end{array}$ \\
\hline Total $^{\mathrm{z}}$ & & & 189 & 499 & 4,867 & $\cdots$ & 4,031 \\
\hline 1995 & $\begin{array}{r}3.5 \\
10.5 \\
17.5 \\
24.5 \\
31.5 \\
38.5 \\
45.5 \\
52.5 \\
59.5\end{array}$ & $\begin{array}{l}10.5 \\
21.0 \\
31.5 \\
42.0 \\
52.5 \\
63.0\end{array}$ & $\begin{array}{c}48(42.5) \\
33(29.3) \\
11(9.7) \\
8(7.0) \\
9(8.0) \\
4(3.5) \\
\ldots \\
\ldots \\
\ldots\end{array}$ & $\begin{array}{c}20(19.8) \\
28(27.7) \\
15(14.9) \\
12(11.9) \\
16(15.8) \\
10(9.9) \\
\ldots \\
\ldots \\
\ldots\end{array}$ & $\begin{array}{c}599(84.5) \\
33(4.6) \\
18(2.5) \\
13(1.8) \\
11(1.5) \\
17(2.5) \\
8(1.1) \\
5(0.7) \\
6(0.8)\end{array}$ & $\begin{array}{c}16(22.9) \\
12(17.1) \\
12(17.1) \\
11(15.7) \\
11(15.7) \\
8(11.5) \\
\ldots \\
\ldots \\
\ldots\end{array}$ & $\begin{array}{c}163(49.6) \\
30(9.0) \\
24(7.3) \\
24(7.3) \\
24(7.3) \\
24(7.3) \\
24(7.3) \\
16(4.9) \\
\ldots\end{array}$ \\
\hline Total & & & 113 & 101 & 710 & 70 & 329 \\
\hline
\end{tabular}

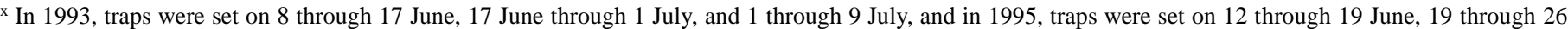
June, and 26 June through 4 July.

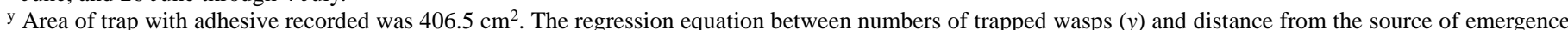
in meters $(x)$ for 1993 and each direction are south, $y=106-6.1 x+0.090 x^{2}, R^{2}=0.94, P=0.0038$; southeast, $y=467-20.5 x+0.220 x^{2}, R^{2}=0.98, P=$ 0.0028 ; west, $y=3,351-187 x+2.34 x^{2}, R^{2}=0.68, P=0.0339$; and east, $y=2,943-6,181 x+2.53 x^{2}, R^{2}=0.73, P=0.0390$. The regression equation between numbers of trapped wasps $(y)$ and distance from the source of emergence in meters $(x)$ for 1995 and each direction are south, $y=60-3.4 x+0.052 x^{2}, R^{2}=$ $0.96, P=0.0083$; southeast, $y=26-0.24 x, R^{2}=0.54, P=0.0953$; west, $y=503-28.5 x+0.36 x^{2}, R^{2}=0.65, P=0.0439$; southwest, $y=16-0.12 x, R^{2}=$ $0.83, P=0.0116$; and east, $y=151-8.1 x+0.11 x^{2}, R^{2}=0.68, P=0.0544$.

$\mathrm{z}$ Total number of wasps trapped during the season.

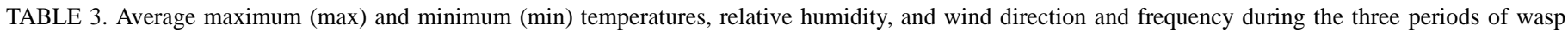
trapping in an experimental Calimyrna orchard at Kearney Agricultural Center, Parlier, CA, during June and July 1993 and 1995

\begin{tabular}{|c|c|c|c|c|c|c|c|}
\hline \multirow[b]{2}{*}{ Period } & \multicolumn{2}{|c|}{ Average temperature $\left({ }^{\circ} \mathrm{C}\right)^{\mathrm{z}}$} & \multicolumn{2}{|c|}{ Average relative humidity ${ }^{\mathrm{z}}$} & \multicolumn{3}{|c|}{ Wind direction and frequency (days) ${ }^{\mathrm{z}}$} \\
\hline & Max & Min & Max & Min & Northwest & West & Southeast \\
\hline \multicolumn{8}{|l|}{1993} \\
\hline 8-17 June & 31.3 & 12.9 & 58.2 & 47.0 & 7 & 2 & 1 \\
\hline 17 June to 1 July & 34.9 & 15.3 & 56.3 & 46.6 & 6 & 7 & 1 \\
\hline 1-9 July & 34.7 & 16.1 & 57.4 & 47.9 & 1 & 7 & 0 \\
\hline \multicolumn{8}{|l|}{1995} \\
\hline 12-19 June & 26.2 & 11.1 & 86.7 & 36.5 & 7 & 0 & 1 \\
\hline 19-26 June & 26.7 & 15.3 & 89.3 & 24.8 & 6 & 0 & 1 \\
\hline 26 June to 4 July & 33.8 & 16.6 & 87.7 & 25.7 & 5 & 3 & 0 \\
\hline
\end{tabular}

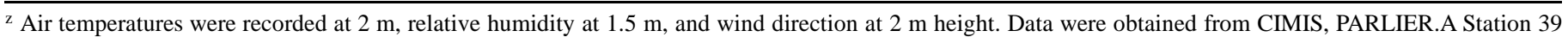
$\left(36^{\circ} 36 \mathrm{~min} \mathrm{~N} ; 119^{\circ} 30 \mathrm{~min} \mathrm{~W}\right.$; elevation $\left.112.3 \mathrm{~m}\right)$. 
was higher than $70 \%$ when more than 150 wasps were recorded per trap during the same sampling period.

Secondary spread. In 2 of 3 years, in all of the orchards sampled, covering Calimyrna shoots with cotton organdy bags resulted in significantly higher levels of endosepsis than on fruits from uncovered shoots (Table 4). In 1990, fruits from both covered and uncovered shoots had similar levels of endosepsis. Over the 3-year study, fruits from orchards 2 and 3 had significantly higher levels of endosepsis in covered shoots than those from orchard 1. Other prevalent fungi recorded in or on figs from the experiment on secondary spread of endosepsis were Alternaria alternata, Ulocladium spp., Aspergillus (section Nigri) spp., Rhizopus spp., and Penicillium. spp. Alternaria and Aspergillus (section Nigri) spp. also developed in fruit-to-fruit contact spots, primarily on covered rather than uncovered figs (data not shown).

\section{DISCUSSION}

Propagules of $F$. verticillioides are first introduced into the Calimyrna syconium at pollination when fig wasps enter the syconium $(2,18,21)$. Growth and sporulation of $F$. verticillioides on the wasp instead of on the tissues of immature Calimyrna fruit suggests that immature (green) syconia of Calimyrna figs are resistant to infection by $F$. verticillioides. Immature fruit contains high amounts of latex, which inhibits germination of conidia and growth of germ tubes of $F$. verticillioides (31), preventing pathogen growth. Because the ostiolar scales are tightly closed, the conditions in the syconium's cavity should be ideal for growth of $F$. verticillioides, but apparently, when fruit are immature only the wasp's body offers a suitable substrate for $F$. verticillioides growth. ( $F$. verticillioides $[F$. moniliforme $]$ has been reported as a pathogen of insects, such as borers [3,33] and gypsy moths [10].) As fruit mature, however, the amount of latex decreases (31) and the sugar content increases $(27,31)$ - two processes that can favor the spread of the pathogen from the infested wasp to fruit tissues. Mycelial strands were observed extending from infested wasps to maturing fruit. $F$ verticillioides also can develop similarly in syconia of all immature caprifig crops (21).

Spread of plant diseases may be affected by the weather conditions and sporulation patterns of pathogens. A number of aerial diseases are spread by wind currents, splashing rain, or insects.

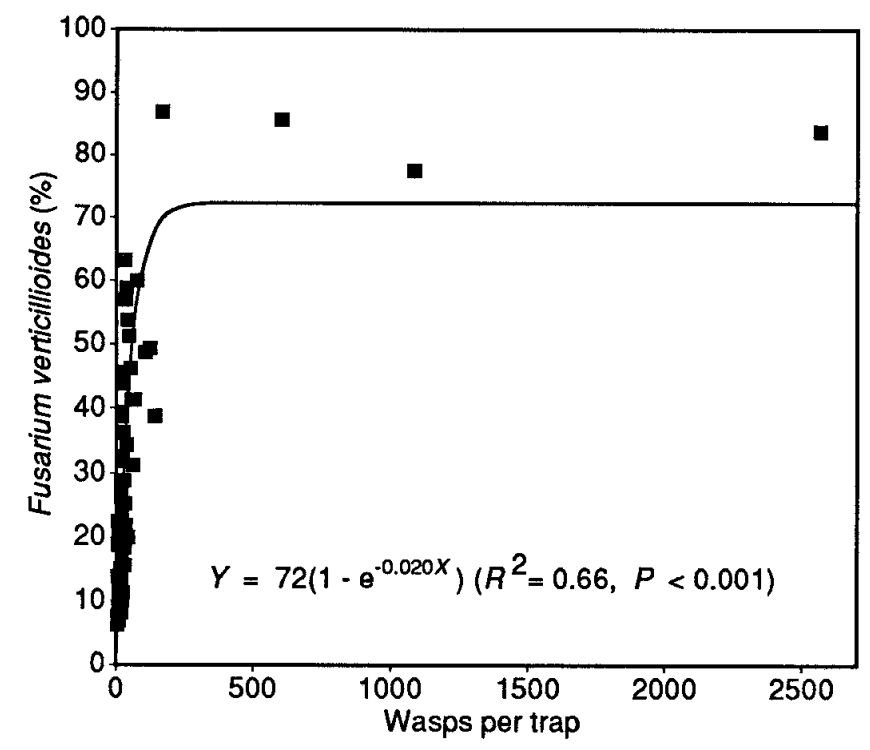

Fig. 8. Relationship between number of wasps captured per trap hung on Calimyrna trees and levels of contamination of immature fruit by Fusarium verticillioides in an experimental orchard in Parlier, CA. Data are based on 31 traps and 40 figs per tree from 31 Calimyrna trees and are combined for 1993 and 1995.
Because the microconidia of $F$. verticillioides develop and initiate disease inside the cavity of fig syconium, their spread is entirely dependent on the fig wasp pollinator, which can disseminate the pathogen spores from infected spring crop caprifigs to healthy Calimyrna figs during the pollination process. Because there is no evidence of secondary spread of fig endosepsis, levels of disease should relate directly to the number of wasps that can successfully enter a fig syconium (18) and the levels of wasp contamination. The number of wasps entering each fig syconium depends on the density of flying wasps and availability of receptive hosts (18), and the level of wasp contamination depends on the cleanliness of caprifigs $(11,21)$. Therefore, the incidence of endosepsis in Calimyrna figs is a function of three parameters: incidence of endosepsis in caprifigs, which directly affects the levels of contamination of wasps with $F$. verticillioides; number of caprifigs hung per Calimyrna tree; and number of wasps entering a Calimyrna syconium (18).

Both the wasp trapping and examination of wasp numbers in fruits suggest that most wasps stay close to the source when a receptive crop is present, suggesting that only caprifig trees found among Calimyrna trees or not farther than $50 \mathrm{~m}$ from an orchard border could affect endosepsis levels in an orchard, and these trees should be destroyed.

The height (low versus high), location (direct sunlight versus shaded), and direction of the canopy (north versus south) of trees in commercial orchards did not affect the levels of endosepsis. This could be the effect of the uniform pollination fig growers attempt to achieve by hanging one bag containing 10 to 20 spring crop caprifigs per tree. Because more than $80 \%$ of the wasps stay within the canopy $3.5 \mathrm{~m}$ from the emergence site, the number of caprifigs hung per tree should influence the incidence of endosepsis in each tree. Therefore, a uniform spread of fig wasps in an

TABLE 4. Effect of covering fruit with cotton organdy bags on secondary spread of endosepsis, caused by Fusarium verticillioides, of Calimyrna figs in three commercial orchards during 1989 through 1991

\begin{tabular}{|c|c|c|c|c|c|}
\hline \multirow[b]{2}{*}{ Orchard $^{u}$} & \multirow[b]{2}{*}{ Year } & \multicolumn{4}{|c|}{ Fruit with endosepsis $(\%)^{\mathrm{v}}$} \\
\hline & & $\begin{array}{l}\text { Covered } \\
\text { shoots }\end{array}$ & $\begin{array}{l}\text { Uncovered } \\
\text { shoots }\end{array}$ & $P$ & $\begin{array}{c}\text { LSD } \\
(P<0.05)\end{array}$ \\
\hline 1 & $\begin{array}{l}1989 \\
1990 \\
1991\end{array}$ & $\begin{array}{r}2.5 \mathrm{a}^{\mathrm{x}}(7)^{\mathrm{y}} \\
3.9 \mathrm{a}(24) \\
32.1 \mathrm{a}(17)\end{array}$ & $\begin{array}{c}9.6 \mathrm{a}(7) \\
15.4 \mathrm{a}(25) \\
4.7 \mathrm{~b}(13)\end{array}$ & $\begin{array}{r}0.093 \\
0.159 \\
<0.001\end{array}$ & $\begin{array}{r}8.7 \\
16.3 \\
11.4\end{array}$ \\
\hline 2 & $\begin{array}{l}1989 \\
1990 \\
1991\end{array}$ & $\begin{array}{l}16.1 \mathrm{a}(7) \\
20.6 \mathrm{a}(26) \\
24.2 \mathrm{a}(16)\end{array}$ & $\begin{array}{c}6.1 \mathrm{~b}(7) \\
15.0 \mathrm{a}(25) \\
14.9 \mathrm{a}(15)\end{array}$ & $\begin{array}{l}0.030 \\
0.135 \\
0.227\end{array}$ & $\begin{array}{r}8.9 \\
7.3 \\
15.5\end{array}$ \\
\hline 3 & $\begin{array}{l}1989 \\
1990 \\
1991\end{array}$ & $\begin{array}{l}42.0 \mathrm{a}(7) \\
13.0 \mathrm{a}(14) \\
12.6 \mathrm{a}(17)\end{array}$ & $\begin{array}{r}12.2 \mathrm{a}(7) \\
7.4 \mathrm{~b}(14) \\
3.7 \mathrm{~b}(15)\end{array}$ & $\begin{array}{l}0.027 \\
0.202 \\
0.029\end{array}$ & $\begin{array}{r}26.2 \\
8.7 \\
7.4\end{array}$ \\
\hline All orchards & $\begin{array}{l}\text { mbine } \\
1989 \\
1990 \\
1991\end{array}$ & $\begin{array}{l}20.2 \mathrm{a}(21) \\
12.6 \mathrm{a}(64) \\
23.0 \mathrm{a}(50)\end{array}$ & $\begin{array}{r}9.3 \mathrm{~b}(21) \\
13.5 \mathrm{a}(64) \\
7.9 \mathrm{~b}(43)\end{array}$ & $\begin{array}{r}0.009 \\
0.810 \\
<0.001\end{array}$ & $\begin{array}{r}11.2 \\
7.2 \\
7.1\end{array}$ \\
\hline $\begin{array}{c}\text { All years con } \\
\text { Orchard } 1 \\
\text { Orchard } 2 \\
\text { Orchard } 3\end{array}$ & ined & $\begin{array}{l}13.7 \mathrm{~b}^{\mathrm{z}}(48) \\
21.1 \mathrm{a}(49) \\
18.1 \mathrm{a}(38)\end{array}$ & $\begin{array}{r}11.4 \mathrm{a}(45) \\
13.6 \mathrm{a}(47) \\
6.8 \mathrm{a}(36)\end{array}$ & $\begin{array}{l}0.660 \\
0.020 \\
0.003\end{array}$ & $\begin{array}{r}10.1 \\
6.3 \\
7.3\end{array}$ \\
\hline
\end{tabular}

"Cultural practices: orchard $1=$ disc/flood; orchard $2=$ noncultivation/drip; and orchard 3 = cover crop/drip; all orchards were located in Merced County, CA.

${ }^{v}$ Disease was determined after splitting each fig in half and observing with a dissecting microscope (magnification 10 to $20 \times$ ).

${ }^{\text {w }}$ Shoots were covered on 15 July 1989, 14 July 1990, or 10 July 1991, and all fruits per shoot from covered and uncovered shoots were harvested on 31 August 1989, 6 September 1990, or 26 September 1991.

x Comparisons between years, using the least significance (LSD) test at $P=$ 0.05 . Values within columns followed by different letters are significantly different.

y Number of replicate shoots with 10 to 24 fruits per shoot.

${ }^{\mathrm{z}}$ Comparisons between orchards, using the LSD test at $P=0.05$. Values within columns followed by different letters are significantly different. 
orchard should result in a uniform spread of endosepsis. However, when a major source of contamination (i.e., a caprifig tree or a forgotten box containing spring crop caprifigs) is present in a Calimyrna orchard, at the border, or in close proximity to the border, endosepsis levels could be higher, especially in fruits of the trees closest to the source, as was shown in this study.

Wild caprifigs can serve as uncontrollable sources of wasp pollinators and can undoubtedly affect fig endosepsis levels in a commercial orchard but only if these caprifigs are located within the orchard, at the border, or not farther than $50 \mathrm{~m}$ from the border. In addition, wasps flying from wild caprifigs usually carry strains of $F$. verticillioides, which are far more virulent than those existing in cultivated caprifig orchards (30). Therefore, growers should remove such wild caprifigs or eliminate foci of contamination by destroying the spring crop caprifigs (i.e., by spraying ethrel before emergence of wasps [5]). Instead, growers should use spring crop caprifigs for pollination from orchards where fungicide treatments are employed to reduce endosepsis $(21,25)$.

The disease spread experiments in both commercial and experimental orchards showed that endosepsis disease follows patterns of typical spread for airborne diseases from the point source (15), even though airborne inoculum per se does not exist; the microconidia of the pathogen become airborne via airborne wasps (18). Therefore, the patterns of behavior and movement of wasps directly affect the disease gradients. The hollow curves, which are characteristic for airborne pathogens, were more pronounced for trees south and southeast than for trees in other directions from the source in the commercial orchard. Essentially, disease levels of fruit collected from trees only to the south and southeast of the point source were affected. Ware and Compton (36) showed that dispersal of adult female fig wasps is wind and temperature dependent. Because the prevailing winds in Fresno County are northwesterly or westerly, our results suggest that the majority of wasps in the commercial orchard flew south and southeast, affecting endosepsis levels in fruit collected from trees downwind from the source. Furthermore, the decreases in numbers of wasps trapped were sharper for the east and west than for the south, southeast, or southwest, suggesting wasps are blown downwind. This is the first record of disease gradients for a disease that develops inside the cavity of a fruit, although disease gradients from the source have been reported for many airborne diseases $(9,14,15)$.

In general, similar gradients of disease were recorded in 1993 and 1995 at the experimental plot at the Kearney Agricultural Center, Parlier. When too many wasps are present in the canopy of a given tree size, the proportion of available receptive figs is smaller, and thus, more wasps enter per syconium. For instance, in 1995 more than $80 \%$ of the wasps that flew to the west were trapped in the west tree, $3.5 \mathrm{~m}$ from the source, resulting in $85 \%$ endosepsis of fruits sampled from this tree (Fig. 7C). This process is called overcaprification for caprifigs and overpollination for edible figs (18). Because overpollination leads to more endosepsis (18), to avoid it, growers split figs and carefully examine the number of wasps in a fig syconium. Trapping wasps in fig orchards with yellow adhesive traps can provide another way for growers to monitor areas where overpollination is suspected, especially because other methods of trapping and counting fig wasps are very difficult (23).

Most disease assessments are host-based, in that the host plant or plant organ is the unit of disease assessment (15). Although this can be the basis for assessing endosepsis, it also is possible to assess the disease in Calimyrna orchards by monitoring the wasp populations. Therefore, wasp trapping might be used as a method to predict the incidence of endosepsis. Brostein (1) and Kjellberg et al. (16) reported that when a receptive crop is present close to a contamination source most of the wasps enter receptive figs as close as possible to the tree from which they emerged. In our study more wasps were counted in figs collected from the first trees south and southeast of the source than from the second or third trees from the source. In commercial Calimyrna orchards, we observed that wasps that emerged from the spring crop caprifigs preferred to remain in the canopy of the same trees to search for receptive figs (T. J. Michailides, unpublished data). Although fig wasps are small and short lived (16), some observations suggest that, at least on occasion, they are capable of long-distance dispersal $(4,32)$. Nason et al. (23) reported that fig wasps are efficient agents of long-distance dispersal, routinely moving up to $10 \mathrm{~km}$ between flowering trees. Our study, however, showed that fig wasps prefer to remain close to the figs from which they have emerged when there are receptive figs close. In the experimental orchard, the east and west trees were located only $3.5 \mathrm{~m}$ from the source of wasp emergence and were visited by more than 33 and $41 \%$ of the total trapped wasp population, respectively.

In general, the primary disease gradients, defined as consisting of infections that all come from the source (9), as recorded in this study, were steeper in the experimental orchard than in the commercial orchard. Both secondary spread and background contamination flatten a primary gradient (9). Because there is no secondary spread of endosepsis, the background contamination can explain the flattened primary disease gradient recorded in the commercial orchard where the grower performed normal pollination. Similarly, Ware and Compton (36) showed that dispersal of adult female fig wasps is wind dependent. The results of this study substantiate complaints of Calimyrna growers against neighbors who grow caprifig trees only upwind of their orchards' borders and only if these trees are located no farther than $50 \mathrm{~m}$ from the orchard border.

Because the number of wasps was related positively to the incidence of endosepsis and negatively to the distance from the source, the negative relationship of distance from the pollinator source and incidence of disease can only be explained by the decline in the number of wasps with distance from the source. Ware and Compton (35) determined for another fig wasp (Elisabethiella beijnathi) that the likelihood of successful location and subsequent arrival at a new host tree is dependent on distance and environmental factors (wind and temperature). In our study, also, more wasps were trapped to the south of the wasp source than to the east or west of the source. Because a wasp's flight can be easily influenced by the prevailing wind currents (35), the number of wasps that caught on traps to the south decreased more slowly than the number of wasps caught on traps in the other directions.

Endosepsis can be characterized as a "monocyclic airborne" disease on Calimyrna figs because there is no secondary spread. In half of the experiments during the 3-year period, there was no difference between covered and uncovered shoots, but in the rest of the experiments, more disease developed in covered shoots than in those left uncovered. Covering the shoot may favor survival of the fungal pathogen during the last part of hot California summers. We noticed that covering figs also favored the development of "contact-spot" diseases, caused by either Alternaria or Aspergillus spp., which developed on fruit-to-fruit contact surfaces, but did not apparently affect incidence of endosepsis. In addition, covering shoots created shading of fruit and perhaps protected fungal infections from the excessive heat of summer in the Central Valley of California. Although nitidulid beetles (Carpophilus spp.) are very common in fig orchards (28), they cannot contribute to spread of endosepsis, because by the time these insects become active in the Calimyrna orchards the figs are close to completing drying, and development of $F$. verticillioides may be inhibited.

In their attempts to pollinate larger numbers of Calimyrna fruit, growers may overlook the presence of caprifig trees within the orchard, at the borders, or in close proximity to the borders and, thus, create situations for greater incidence of endosepsis. The presence of caprifigs in a Calimyrna orchard can create endosepsis foci that extend 30 to $50 \mathrm{~m}$ in diameter but do not form secondary foci. Therefore, the removal of caprifigs from edible fig orchards is strongly recommended. 


\section{ACKNOWLEDGMENTS}

Research support provided by the California Fig Institute and the California Dry Fig Advisory Board, Fresno. We thank W. Butler, K. Herman, J. Eirich, R. Jura, W. Goldberg, P. Mesplé, and R. M. DeBenedetto for providing Calimyrna figs and allowing us to use trees in their orchards. We also thank J. Chevalier and his crew for performing all the cultural practices of the fig orchards at Kearney Agricultural Center, Parlier. We thank M. Doster, R. Kölliker, L. Boeckler, L. Hou, M. Ruepp, and K. Tsuda for technical help, R. Klamm, director of the California Fig Institute, for his excellent cooperation in this research, and K. V. Subbarao and C. X. Hong for reviewing this manuscript and making constructive suggestions.

\section{LITERATURE CITED}

1. Brostein, J. L. 1989. A mutualism at the edge of its range. Experientia 45:622-637.

2. Caldis, P. D. 1927. Etiology and transmission of endosepsis (internal rot) of the fruit of the fig. Hilgardia 2:287-328.

3. Clayton, N., and Grove, J. F. 1982. Fusarium as an insect pathogen. Pages 117-128 in: The Applied Mycology of Fusarium. M. O. Moss and J. E. Smith, eds. Symp. Br. Mycol. Soc. Cambridge University Press, London.

4. Compton, S. G. 1993. A collapse of host specificity in some South African fig wasps. S. Afr. J. Sci. 86:39-40.

5. Crane, J. C., Marei, N., and Nelson, M. M. 1970. Ethrel speeds growth and maturity of figs. Calif. Agric. 24 (3):8-10.

6. Doster, M. A., Michailides, T. J., and Morgan, D. P. 1996. Aspergillus species and mycotoxins in figs from California orchards. Plant Dis. 80: 484-489.

7. Ferguson, L., Michailides, T. J., and Shorey, H. H. 1990. The California fig industry. Hortic. Rev. 12:409-490.

8. Galil, J. 1977. Fig biology. Endeavor 1:52-56.

9. Gregory, P. H. 1968. Interpreting plant disease dispersal gradients. Annu. Rev. Phytopathol. 6:189-212.

10. Hajeck, A. E., Nelson, P. E., and Humber, R. A. 1993. Two Fusarium species pathogenic to gypsy moth, Lymantria dispar. Mycologia 85:937-940.

11. Hansen, H. N. 1928. Endosepsis and its control in caprifigs. Phytopathology 18:931-938.

12. Hansen, H. N. 1929. Thrips as carriers of fig-decaying organisms. Science 69:356-357.

13. Herre, E. A. 1996. An overview of studies on a community of Panaminian figs. J. Biogeogr. 23:593-607.

14. Ingold, T. 1971. Spores in the air. Pages 173-199 in: Fungal Spores Their Liberation and Dispersal. Clarendon Press, Oxford.

15. Jeger, M. J., III 1990. Mathematical analysis and modeling of spatial aspects of plant disease epidemics. Pages 53-95 in: Epidemics of Plant Diseases, J. Kranz, ed., Springer-Verlag, New York.

16. Kjellberg, F., Doumesche, B., and Brostein, J. L. 1988. Longevity of a fig wasp (Blastophaga psenes). Prok. K. Ned. Akad. Wet. (C) 91:117-122.

17. Klittich, C. J. R., Nelson, P. E., and Marasas, W. F. O. 1997. Fusarium thapsinun (Gibberella thapsina): A new species in section Liseola from sorghum. Mycologia 89:643-652.
18. Michailides, T. J., and Morgan, D. P. 1994. Dynamics of Blastophaga psenes populations, availability of caprifigs, and fig endosepsis caused by Fusarium moniliforme. Phytopathology 84:1254-1263.

19. Michailides, T. J., and Morgan, D. P. 1997. Spread of endosepsis disease caused by Fusarium moniliforme in Calimyrna fig orchards in California. Page 24 in: Abstr. 1st Int. Symp. Fig. U. Aksoy, ed., Ege University, Faculty of Agriculture, Izmir, Turkey.

20. Michailides, T. J., Morgan, D. P., and Klamm, R. 1994. Comparison of three methods for determining fig endosepsis caused by Fusarium moniliforme and other molds in caprifigs and Calimyrna figs. Plant Dis. 78:44-50.

21. Michailides, T. J., Morgan, D. P., and Subbarao, K. V. 1996. Fig endosepsis: An old disease still a dilemma for California growers. Plant Dis. 80:828-841.

22. Michailides, T. J., Ogawa, J. M., and Ferguson, L. 1988. Investigations on the correlation of fig endosepsis on Calimyrna with caprifig infestations by Fusarium moniliforme. Annual Fig Research Report for Crop Year 1987. California Fig Institute, Fresno.

23. Nason, J. D., Herre, E. A., and Hamrick. J. 1996. Paternity analysis of the breeding structure of strangler fig populations: Evidence for longdistance wasp dispersal. J. Biogeogr. 23:501-512.

24. Nelson, P. E., Toussoun, T. A., and Marasas, W. F. O. 1983. Fusarium Species: An Illustrated Manual for Identification. Pennsylvania State University Press, University Park.

25. Obenauf, G. L., Gerdts, M., Leavitt, G., and Crane, J. 1978. Commercial dried fig production in California. Div. Agric. Sci., Univ. Calif., Berkeley. Leafl. 21051.

26. Obenauf, G. L., Ogawa, J. M., Lee, K., and Frate, C. A. 1982. Fungicide control of molds that attack caprifigs. Plant Dis. 66:566-567.

27. Phillips, E. H., Smith, E. H., and Smith, R. E. 1925. Fig smut. Bull. 387. University of California Printing Office, Berkeley.

28. Smilanick, J. M. 1979. Colonization of ripening figs (Ficus carica) by Carpophilus spp. J. Econ. Entomol. 72:557-565.

29. Smith R. E., and Hansen, H. N. 1935. Directions for control of endosepsis in figs. 1934-1995. California Agricultural Experiment Station, University of California, Berkeley.

30. Subbarao, K. V., and Michailides, T. J. 1993. Virulence of Fusarium species causing fig endosepsis in cultivated and wild caprifigs. Phytopathology 83:527-533.

31. Subbarao, K. V., and Michailides, T. J. 1996. Development of phenological scales for figs and their relative susceptibilities to endosepsis and smut infection. Plant Dis. 80:1015-1021.

32. Thorton, I. W. B., Compton, S. G., and Wilson, C. N. 1996. The role of animals in the colonization of the Krakatau islands by fig trees (Ficus species). J. Biogeogr. 23:577-592.

33. Vago, C. 1958. Virulence cryptogamique simultanée vis-a-vis d'un vegetal et d'un insecte. C. R. Hebd. Seances Acad. Sci. 247:1651-1653.

34. van Noort, S., and Compton, S. G. 1996. Convergent evolution of agaonine and sycoecine (Agaonidae: Chalcidoidea) head shape in response to the constraints of host fig morphology. J. Biogeogr. 23:415-424.

35. Ware, A. B., and Compton, S. G. 1994. Dispersal of adult female fig wasps. 1. Arrivals and departures. Entomol. Exp. \& Appl. 73:221-229.

36. Ware, A. B., and Compton, S. G. 1994. Dispersal of adult female fig wasps. 2. Movements between trees. Entomol. Exp. \& Appl. 73:231-238.

37. Warner, R. M. 1961. Fig research. Calif. Fig Inst. 14(3):1-2. 